\title{
Perilaku Menyontek Ditinjau dari Prokrastinasi Akademik pada Pelajar SMA Yos Sudarso
}

\author{
Charlie Sanlie, Winida Marpaung, Rianda Elvinawanty \\ Universitas Prima Indonesia, Medan, Indonesia \\ Email : Charliesanlie@gmail.com
}

\begin{abstract}
The purpose in this study is to find out the relation between academic cheating and academic procrastinations. Academic procrastination is the act of someone who replaces the implementation of more important things with tasks that are not too important, or doing things that are more fun to do so that procrastinating important tasks to another day (Newton, 2014). The researchers assuming there was a positive relationship between variable academic cheating and academic procrastinations. Participants for this study collected by a disproportionate stratified random sampling method and the sample in this research are 139 students at SMA Yos Sudarso Medan. The correlation coefficient obtained was $0.562(p<0.05)$. These results show that there is a absolute and significant relationship between academic cheating and academic procrastinations.
\end{abstract}

Keywords : Academic procrastination, Student, Academic Cheating

\begin{abstract}
ABSTRAK
Penelitian ini mempunyai tujuan untuk mengetahui relasi antara perilaku menyontek dengan prokrastinasi akademik. Prokrastinasi akademik merupakan tindakan seseorang yang menggantikan pelaksanaan hal yang lebih penting dengan tugas yang tidak terlalu penting, atau mengerjakan hal yang lebih senang dilakukan sehingga menunda-nunda tugas penting ke lain hari (Newton, 2014). Peneliti berasumsi bahwa terdapat hubungan positif antara perilaku menyontek dan prokrastinasi akademik. Partisipan dalam penelitian ini diambil menggunakan metode disproportionate stratified random sampel dengan jumlah 139 murid pada SMA Yos Sudarso Medan. Koefisien korelasi yang didapatkan sebesar $0.562(\mathrm{p}<0.05)$. Hasil ini menyatakan bahwa ada nilai signifikan absolut antara perilaku menyontek dan prokrastinasi akademik
\end{abstract}

Kata Kunci : Prokrastinasi akademik, Murid, Perilaku menyontek

\section{Pendahuluan}

Masyarakat memiliki peran dan tugas yang banyak dalam menjalankan kesejateraan negeri. Dalam menjalankan tugas dan peran tersebut, masyarakat diharapkan untuk memiliki pendidikan yang cukup baik. Menurut Hamalik (2001), pendidikan adalah suatu proses dalam pribadi pelajar supaya mampu menyesuaikan diri dengan lingkungan dan mampu menimbulkan perilaku yang memungkinkan untuk merubah lingkungan menjadi lebih bermanfaat dalam kehidupan masyarakat. Di dalam sekolah siswa diwajibkan untuk mampu menyampaikan materi-materi yang telah dipahami di dalam kelas dan tidak heran jika prestasi dari seorang murid dilihat dari nilai yang didapatkan bukan melalui proses pada saat pembelajaran di dalam sekolah.

Arijanto, P., (2016) melakukan penelitian terhadap beberapa siswa yang mengikuti Ujian pada tingkat akhir dan mendapatkan bahwa siswa mengalami tingkatan stress dimana siswa akan merasa terkucil, gelisah, tidak dapat berkonsentrasi, dan juga ketegangan pada masa-masa ujian akhir. Ketakutan pada murid yang mendorong murid untuk melakukan tindakan curang pada akademis. Seperti kasus yang ada pada kota Bandung tahun 2016, lima siswa diketahui menyalin jawaban dari selembar kertas sebelum ujian Bahasa Indonesia dimulai. Dadang selaku tim pemantau yang memergoki siswa secara bersamaan menyalin jawaban ke kertas kecil yang akan dibawa masuk ke dalam ruang ujian. Setelah ditelusuri, sumber kertas tersebut tidak jelas bahkan jawaban yang ada pada kertas tidak benar. (www.national.tempo.co)

Atas hasil wawancara yang dilaksanakan kepada murid SMA Yos Sudarso Medan, peneliti mendapatkan berbagai informasi bahwa siswa sering sekali tidak mengerjakan tugas, menyalin hasil karya teman, meminta bantuan teman saat kuis dadakan berlangsung, bahkan ada yang mengaku menulis materi ujian di dinding atau kertas kecil yang akan dibawa masuk kedalam ruang ujian. Tindakan-tindakan tersebut disebut sebagai tindakan curang dalam akademis ataupun perilaku menyontek. McCabe dan Trevino (dalam Whitley \& Speigel, 2002) mengungkapkan perilaku 
menyontek sebagai tindakan ketika seseorang berani mengaku hasil yang disalin dari teman merupakan hasil karya sendiri, menggunakan catatan kecil yang tidak diperbolehkan, ataupun membantu teman pada saat ujian berlangsung.

Roig dan Detammaso (1995) melakukan penelitian terhadap tindakan menyontek dan salah satu aspek yang mempengaruhi tindakan menyontek ialah prokrastinasi akademik. Hasil penelitian menyatakan kebanyakan siswa yang melakukan prokrastinasi akademik, baik melalui penundaan terhadap tugas maupun penundaan saat belajar, akan lebih memungkinkan melakukan perilaku menyontek dalam mencapai nilai yang diinginkan.

Prokrastinasi akademik merupakan tindakan seseorang yang menggantikan pelaksanaan hal yang lebih penting dengan tugas yang tidak terlalu penting, atau mengerjakan hal yang lebih senang dilakukan sehingga menunda-nunda tugas penting ke lain hari (Newton, 2014). Menunda-nunda tugas penting ini menghasilkan rasa bersalah yang menyebabkan hilangnya motivasi dan produktivitas pribadi. Prokrastinator biasanya mengerjakan pekerjaan saat waktu pengumpulan dekat sehingga siswa akan merasakan kepanikan dari dalam dirinya dan melakukan tindakan menyontek. Buskist dan David (dalam Cizek,1999) berpendapat bahwa siswa yang melakukan prokrastinasi dalam mempelajari materi ujian akan menyebabkan siswa tidak siap dalam ujian dan tidak mampu menjawab pertanyaan yang di ujikan sehingga siswa lebih memilih melakukan tindakan menyontek. Hal ini sejalan dengan hasil penelitian Muslimin dan Hasanah (2016), terhadap 70 subjek pelajar di SMK X Yogyakarta yang menyatakan adanya hubungan positif antara prokrastinasi akademik dan tindakan mencontek. Penelitian menyimpulkan bahwa pelajar yang mempunyai tingkat prokrastinasi akademik lebih tinggi akan lebih memungkinkan melakukan tindakan mencontek dalam akademis, dan sebaliknya.

\section{Metode Penelitian}

Adapun penelitian ini menggunakan metode kuantitatif. Sugiyono (2014) menyampaikan metode penelitian kuantitatif ialah metode yang berupa filsafat positif, yang dimanfaatkan dalam penelitian untuk mengamati populasi dalam sampel tertentu, teknik pengumpulan sampel umumnya acak dengan pengambilan data memanfaatkan sarana penelitian.

Variabel yang terlibat pada penelitian ini berupa perilaku menyontek selaku variabel bebas dan prokrastinasi akademik selaku variabel tergantung. Sampel yang diambil pada penelitian ini ialah pelajar SMA kelas X, XI, dan XII di Yos Sudarso Medan. Jumlah sampel yang diambil menggunakan ketentuan Isaac dan Michael (dalam Sugiyono, 2016) dari populasi sebanyak 230 orang dengan perhitungan taraf kesalahan 5\% adalah minimal sebanyak 139 subjek.

Pengumpulan sampel dalam penelitian ini memanfaatkan teknik disproportionate stratified random sampling. Metode pengambilan data menggunakan metode pembagian skala pengukuran tindakan menyontek dan prokrastinasi akademik. Instrumen yang dipakai pada penelitian merupakan skala Likert.

Skala perilaku mencontek yang digunakan pada penelitian dirangkai bersumber pada faktor perilaku mencontek yang telah diteliti oleh Bashir dan Bala (2018) di antaranya : Cheating on Exam, Prior Cheating, Falsification, Plagiarism, Lying about Academic Assignments, dan outside help. Sedangkan instrumen prokrastinasi akademik yang dipakai pada penelitian ini dirangkai bersumber pada karakteristik prokrastinasi akademik yang dikemukakan oleh Ferrari, dkk., (dalam Ghufron \& Risnawati, 2010) di antaranya : Penundaan dalam mengawali atau menyempurnakan tugas, ketidaksetaraan waktu antara rencana dengan kinerja aktual, keterlambatan saat melaksanakan tugas, dan mengerjakan kegiatan yang lebih disenangi. Hasil penelitian dianalisis menggunakan teknik korelasi Product Moment Pearson.

\section{Hasil Dan Pembahasan}

Penelitian dilakukan pada tanggal 26 Juli -27 Juli 2019 pada 230 siswa SMA Yos Sudarso Medan yang menjadi subjek penelitian. Pengambilan data dimulai dengan membagikan skala penelitian berupa skala perilaku menyontek yang valid sebanyak 38 item dan skala prokrastinasi akademik yang valid sebanyak 39 item. Adapun skala yang telah disusun kembali untuk penelitian ini dapat dilihat pada tabel 1 dan 2 
Tabel 1. Penomoran Baru Skala Perilaku Menyontek Setelah Uji Coba

\begin{tabular}{ccccc}
\multirow{2}{*}{ No. } & $\begin{array}{c}\text { Pengukuran Perilaku } \\
\text { Menyontek }\end{array}$ & Favourable & Unfavourable & Jumlah \\
\cline { 3 - 4 } & Cheating in Examination & $1,7,13,18$ & $14,17,36$ & $\mathbf{7}$ \\
\hline 1. & Plagiarism & $5,12,24$ & $6,21,25$ & $\mathbf{6}$ \\
\hline 2. & Outside Help & $3,15,28$ & $20,27,33$ & $\mathbf{6}$ \\
\hline 3. & Prior Cheating & $11,22,38$ & $9,29,34$ & $\mathbf{6}$ \\
\hline 4. & Falsification & $2,23,26,32$ & 4,37 & $\mathbf{6}$ \\
\hline 5. & $\begin{array}{c}\text { Lying about Academic } \\
\text { Assignments }\end{array}$ & $8,19,30,35$ & $10,16,31$ & $\mathbf{7}$ \\
\hline 6. & Total & $\mathbf{2 1}$ & $\mathbf{1 7}$ & $\mathbf{3 8}$
\end{tabular}

\begin{tabular}{ccccc} 
No. & \multicolumn{2}{c}{ Tabel 2. Penomoran Baru Skala Prokrastinasi Akademik Setelah Uji Coba } \\
& Ciri Prokrastinasi Akademik & \multicolumn{2}{c}{ Butir-butir Pernyataan } & Jumlah \\
\cline { 2 - 3 } & $\begin{array}{c}\text { Pavourable } \\
\text { Penundaan untuk memulai dan } \\
\text { menyelesaikan tugas }\end{array}$ & $1,2,6,35,36$ & $7,8,11,17,33$ & $\mathbf{1 0}$ \\
\hline 1. & $\begin{array}{c}\text { Keterlambatan dalam } \\
\text { mengerjakan tugas }\end{array}$ & $10,14,15,19,37$ & $12,22,28,32$ & $\mathbf{9}$ \\
\hline 2. & $\begin{array}{c}\text { Kesenjangan waktu antara } \\
\text { rencana dan kinerja aktual }\end{array}$ & $16,20,21,25,26$, & $3,4,24,34,39$ & $\mathbf{1 1}$ \\
\hline 3. & 38 & $5,13,21,29,31$ & $\mathbf{9}$ \\
\hline 4. & $\begin{array}{c}\text { Melakukan aktivitas yang lebih } \\
\text { menyenangkan }\end{array}$ & $9,18,23,27$ & $\mathbf{1 9}$ & $\mathbf{3 9}$
\end{tabular}

Berdasarkan tabel tersebut, maka jumlah seluruh aitem yang akan digunakan dalam penelitian adalah berjumlah 39 aitem. Langkah pertama untuk memudahkan pelaksanaan penelitian, skala prokrastinasi akademik dan skala perilaku menyontek digabung dalam satu set eksemplar, yang termasuk di dalamnya adalah (1) kata pengantar skala, (2) identitas subjek, (3) petunjuk pengisian skala, (4) skala prokrastinasi akademik, dan skala perilaku menyontek.

Langkah kedua adalah memberikan nilai dari setiap aitem dalam skala. Pemberian nilai dilakukan dengan melihat kembali bobot dari setiap aitem dan kemudian memasukkan data dengan bantuan Microsoft Excel yang kemudian akan disalin ke SPSS untuk dilakukan analisis data untuk mengetahui hubungan antara kedua variabel. Berdasarkan hasil dari SPSS 20.00 for windows, penelitian pada pelajar SMA Yos Sudarso Medan menunjukkan bahwa rata-rata (mean) untuk variabel perilaku menyontek adalah sebesar 100.58 dengan SD (Standar deviasi) 18.882. Data yang dihasilkan menunjukkan bahwa 16 subjek $(11,5 \%)$ memiliki tingkat perilaku menyontek yang rendah, 87 subjek $(62,6 \%)$ dalam tingkat sedang, dan 36 subjek $(25,9 \%)$ berada dalam tingkat perilaku menyontek tinggi. Peneliti melakukan wawancara terhadap beberapa pelajar dan mereka mengakui bahwa mereka takut akan gagal saat ujian berlangsung, ingin membantu teman yang kurang bisa saat ujian dan beberapa mengaku bahwa mereka tidak sengaja dalam melakukan tindakan tersebut. Respon dari siswa ini selaras dengan hasil penelitian yang telah diteliti oleh Brimble dan Stevenson-Clarke (2005), mengenai berbagai alasan siswa melakukan tindakan menyontek, salah satunya adalah ingin membantu teman sebaya. Sedangkan hasil yang didapatkan pada rata-rata (mean) variabel prokrastinasi akademik berupa 103,57 dan SD (Standar Deviasi) 19,981. terdapat 12 subjek $(8,6 \%)$ berada dalam tingkat prokrastinasi akademik rendah, 91 subjek $(65,5 \%)$ memiliki tingkat prokrastinasi akademik sedang, dan sebanyak 36 subjek $(25,9 \%)$ berada dalam tingkat prokrastinasi tinggi. Peneliti juga melakukan wawancara terhadap siswa tingkat prokrastinasi sedang dan mendapatkan bahwa mereka malas untuk mengerjakan tugas. Peristiwa ini didukung oleh penelitian yang dilakukan Mortazavi, F., dkk., (2015) dalam pengukuran pada prokrastinasi akademik yang menghasilkan 4 
alasan siswa melakukan prokrastinasi akademik, yaitu : takut akan gagal, mengambil resiko, kemalasan, dan pemberontakan. Peneliti melakukan uji asumsi berupa uji normalitas data serta uji linearitas. Data uji asumsi bisa diamati pada tabel berikut.

Tabel 3. Hasil Uji Normalitas

\begin{tabular}{cccccc}
\hline Variabel & SD & KS-Z & Sig & P & Ket \\
\hline Perilaku Menyontek & 18.882 & 0.804 & 0.268 & $\mathrm{p}>0.05$ & Sebaran normal \\
\hline Prokrastinasi Akademik & 18.981 & 0.680 & 0.372 & $\mathrm{p}>0.05$ & Sebaran normal \\
\hline
\end{tabular}

Uji normalitas yang digunakan berupa Kolmogorov Smirnov test. Hasil menunjukkan data memiliki sebaran normal jika p>0,05 (Priyatno, 2011). Uji normalitas pada perilaku menyontek memperoleh hasil signifikansi uji satu arah yaitu 0.268 ( $\mathrm{p}>0.05$ ), bermakna bahwa data dalam variabel perilaku menyontek berdistribusi dan mempunyai sebaran normal. Untuk variabel prokrastinasi akademik diperoleh hasil signifikansi $0.372(\mathrm{p}>0.05)$, yang bermakna variabel prokrastinasi akademik berdistribusi dan sebaran normal.

Tabel 4 . Hasil Uji Linearitas Hubungan

\begin{tabular}{cccc}
\hline Variable & F & Signifikansi & Keterangan \\
\hline Perilaku Menyontek & 109.206 & 0.000 & Linear \\
Prokrastinasi Akademik & & & \\
\hline
\end{tabular}

Bersumber pada tabel 2 maka dapat dinyatakan variabel perilaku menyontek dan prokrastinasi akademik mempunyai relasi linear. Hal ini diketahui dari angka $\mathrm{Sig}=0.000(\mathrm{p}<0,05)$, yang berarti kedua variabel hubungan yang linear.

Tabel 5. Korelasi antara prokrastinasi akademik dengan perilaku menyontek

\begin{tabular}{ccc}
\hline Variabel & Pearson Correlation & Sig $(\mathrm{p})$ \\
\hline $\begin{array}{c}\text { Prokrastinasi Akademik } \\
\text { Perilaku Menyontek }\end{array}$ & 0.562 & 0.000 \\
\hline
\end{tabular}

Pada tabel 3 hasil penelitian menunjukkan koefisien korelasi Product Moment sebesar 0.562 dengan Sig $=0.000(\mathrm{p}<0.05)$, yang bermakna jika semakin tinggi perilaku prokrastinasi akademik pada pelajar maka semakin tinggi juga tingakan menyontek pada pelajar SMA Yos Sudarso Medan, dan juga sebaliknya. Hasil yang diperoleh senada dengan penelitian yang diteliti oleh Ummul,dkk., (2014) dan membuktikan adanya hubungan signifikan positif $(r=0,066, p<0,05)$ antara variabel prokrastinasi akademik dengan perilaku menyontek pada pelajar.

Tabel 6.Sumbangan Efektif

\begin{tabular}{lrrrr} 
Model & R & R Square & Adjusted R Square & Std. Error of the Estimate \\
\hline 1 & $.562^{\mathrm{a}}$ & .316 & .311 & 15.668 \\
\hline
\end{tabular}

Kemudian peneliti menguji besarnya sumbangan efektif dan bisa disimpulkan penelitian ini memperoleh koefisien $\mathrm{R}^{2}=0.316$ yang dapat diartikan bahwa sumbangan 31.6 persen prokrastinasi akademik memberi pengaruh terhadap perilaku menyontek sedangkan selebihnya 68.4 persen dipengaruhi dari faktor lain, yaitu kepercayaan diri, kedisiplinan belajar, motivasi berprestasi, minat belajar, konsep diri, berpikir positif, moral judgement maturity, adversity intelligence, locus of control, religiusitas, dan konformitas teman sebaya yang tidak diteliti oleh peneliti 


\section{Simpulan}

Berdasarkan hasil penelitian yang didapatkan bisa dikatakan bahwa siswa-siswi pada SMA Yos Sudarso Medan memiliki tingkat prokrastinaasi akademik sedang dengan jumlah subjek 91 atau sebesar $65,5 \%$ dan perilaku menyontek yang berada pada tingkat sedang dengan jumlah subjek 87 $(62,6 \%)$.

Dari hasil koefisien $r=0,562$ dapat ditarik kesimpulan bahwa ada hubungan absolut antara varibel prokrastinasi akademik dengan perilaku menyontek terhadap pelajar SMA Yos Sudarso Medan yang berarti semakin tinggi prokrastinasi akademik yang ada pada pelajar, maka semakin positif tingkat perilaku menyontek pada siswa tersebut.

\section{Daftar Rujukan}

[1] Arijanto, P. (2016). Identifikasi tingkat stress peserta didik menjelang ujian nasional pada jenjang pendidikan menengah. Jurnal Psikologi Konseling. 8, (1), 96-100. Diunduh pada tanggal 21 Desember 2018 dari https://docplayer.info/56772471-Identifikasi-tingkat-stres-peserta-didik-menjelang-ujiannasional-pada-jenjang-pendidikan-menengah.html

[2] Bashir, H., \& Bala, R. (2018). Development and validation of academic dishonesty scale presenting a multidimensional scale. International Journal of Instruction. 11, (2), 57-74. Retrieved January 12, 2019 from https://eric.ed.gov/?=EJ8

[3] Brimble, M., \& Stevenson-Clarke, P., (2005). Perceptions of the prevalence and seriousness of academic dishonesty in Australian universities. 32, (3), 19-44. Journal : The Australian Educational Researcher. Retrieved January 19, 2019 from https://files.eric.ed.gov/fu lltext/EJ743503.pdf

[4] Cizek, G. J. (1999). Cheating on tests : How to do it, detect it, and prevent it. Mahwah, NJ : Lawrence Erlbaum.

[5] Ghufron, M. N., \& Risnawati, R. (2010). Teori-teori psikologi. Yogyakarta : Ar-Ruzzmedia.

[6] Hamalik, O. (2001). Proses Belajar Mengajar. Jakarta : Bumi Aksara.

[7] Mortazavi, F., Mortazavi, S. S., \& Khosrorad, R. (2015). Psychometric properties of the Procrastination Assessment Scale-Student (PASS) in a student sample of Sabzevar University of Medical Sciences. 17, (9), 1-8. Iran Red Crescent Med J. Retrieved Desember 20, 2018 from http://libgen.lc/scimag/ads.php?doi=10.5812/ircmj.28328

[8] Muslimin, Z. I. \& Hasanah, M. (2016). Hubungan antara Prokrastinasi Akademik dengan Perilaku Menyontek pada siswa SMK “X” Yogyakarta. Jurnal Psikologi Integratif. 04, (02), 128-137. Diakses pada tanggal 25 juni 2018 dari http://digilib.uin-suka.ac.id/16929/1/07710036

[9] Newton, Paul. (2014). How to overcome procrastination. Ebook : bookboon.com

[10] Priyatno, D. (2011). Buku skala analisis statistik SPSS. Jakarta : Abadi.

[11] Roig, M. \& Detammaso, L. (1995). Are college cheating and plagiarism related to academic procrastinations?. Jurnal psikologi. 77,691-698. Retrieved oktober 22, 2018 fromhttp://libgen.lc/scimag/ads.php?doi=12.723/ircmj.283

[12] Sugiyono. (2014). Metode penelitian. Bandung : Alfabeta.

[13] Ummul, K., Maputra, Y., \& Rahmi, Fitria. (2014). Pengaruh prokrastinasi akademik terhadap perilaku menyontek pada siswi sma di pesantren X. Jurnal RAP UNP. 5, (2), 192-203. Diunduh pada tanggal 25 juli 2018 dari http://ejournal.unp.ac.id/index.ph/psikologi/artikel/6634

[14] Whitley, Jr. B. E, \& Spiegel, P. K. (2002). Academic dishonesty an educator's guide. Unites States of America : Lawrence Erlbaum Associates. 